\title{
Thinning control of conifer plantations in Great Britain
}

\author{
T.J.D. ROLLINSON \\ Forestry Commission Research Station, Alice Holt Lodge, Farnham, Surrey, UK
}

\begin{abstract}
Summary
Thinning practice in Great Britain has been influenced in recent years by the growing recognition of the threat of wind damage to plantations and by the decline in the real price of small roundwood. Current thinning practice in the Forestry Commission is based on assessments of the likelihood of wind damage and the costs and revenues of thinning operations. Where the risk of wind damage is high, no thinning is the preferred option, where the risk of wind damage is moderate, thinning is likely to be done at conventional first thinning ages, and where the risk of wind damage is low, thinning may be delayed by 5 to 10 years. Economic appraisals are carried out to determine whether or not stands should be thinned and if so, how.

The various elements which comprise a thinning regime are described, that is the thinning type, the intensity of thinning, the thinning cycle, the thinning yield and the timing of thinning.

The control system used when marking a stand for thinning is described. The system is based on control of the volume removed in a thinning operation and relies on field assessments of basal area stocking and the volume marked as thinnings.
\end{abstract}

\section{Introduction}

Since the $1940 \mathrm{~s}$ a major programme of afforestation has taken place in Great Britain leading to the creation of extensive areas of even-aged plantations on upland sites in the exposed north and west of the country. There are about 1321000 hectares of mainly coniferous high forest of which 85 per cent is less than 40 years of age (Forestry Commission, 1984). Some 62 per cent of this area is managed by the Forestry Commission. As a result of the type of sites available for planting and the changes in choice of species over the years, the major coniferous species is Sitka spruce (Picea sitchensis (Bong.) Carr.) with 526000 hectares, followed by Scots pine (Pinus sylvestris L.) with 241000 hectares and then Lodgepole pine (Pinus contorta (Dougl.)) with 127000 hectares (Forestry Commission, 1984). The volumes of conifer thinning and felling in Forestry Commission plantations over the past 5 years are shown in table 1 together with estimates of future wood production in 1992 and 1997 . The volumes clearfelled have progressively increased whilst the volumes of thinning have fallen despite substantial recruitment into the age classes usually considered for first thinning.

Thinning practice may be determined by reference to many different criteria. In Great Britain the thinning practice which is likely to be most profitable in the long 
TABLI: 1

Volume of timber thinned and felled 1980-1984 and estimates of future production

in Forestry Commission plantations. Conifers only. Thousands of cubic metres over-bark.

Volume du bois éclairci et abattu 1980-1984 et évaluations de la production future des plantations de la Forestry Commission. Conifères seulement. Par $1000 \mathrm{~m}^{3}$ sur écorce.

\begin{tabular}{c|c|c|c}
\hline Year & Thinned & Felled & Total \\
\hline 1980 & 1750 & 1610 & 3360 \\
1981 & 1530 & 1730 & 3260 \\
1982 & 1430 & 2120 & 3550 \\
1983 & 1300 & 2410 & 3710 \\
1984 & 1360 & 2510 & 3870 \\
1992 & & & 7000 \\
1997 & & & 8800 \\
\hline \hline
\end{tabular}

term is usually chosen. Economic appraisals are carried out to determine whether or not stands should be thinned and if they are to be thinned, how. In recent years important changes in thinning practice have taken place in Great Britain. The threat of wind damage to exposed even-aged plantations and the decline in the real price of small roundwood have led to an increasing area of plantations being managed on nothin regimes. The impact of these factors in determining thinning practice is discussed in the first section of this paper. The second section describes the various elements which comprise a thinning regime for stands in a forest which are to be thinned. The final section describes the control system recommended to be used when marking an individual stand for thinning.

\section{Thinning practice}

\subsection{Wind damage}

The threat of wind damage is often the most important factor determining thinning policy. Wind damage can be classified as catastrophic or endemic. Catastrophic wind damage results from severe storms while endemic damage commences as small pockets of windblown trees, which spreads progressively through a stand over a period of years. Although catastrophic wind damage is locally severe, endemic wind damage is more serious. Over the last 30 years, the volume of timber damaged as a direct result of catastrophic storm damage has been estimated at about 6 per cent of the total production programme during that period. In contrast, the proportion of timber harvested prematurely as a result of endemic wind damage has been estimated at about 20 per cent of the total production programme over the same period (ATTERSON, 1980 ; Miller, 1983). About 80 per cent of young plantations in the uplands lie on exposed sites with poorly drained soils on which stands are shallow rooted so an increasing proportion of future harvesting programmes in Great Britain can be expected to come from wind damaged stands (MILLER, 1985). A system of classifying wind damage susceptibility by windthrow hazard classes has been in use for several years (Booth, 
1979 ; Miller, 1985). Six hazard classes are recognised and each class defines the stand top height when endemic wind damage will commence. It is generally recognised that crops liable to windblow will stand longer if left unthinned than if thinned. In the Forestry Commission, economic appraisals have led to the decision not to thin crops in areas of high windthrow hazard. Analysis of data published in yield tables (EDwArDS \& CHRISTIE, 1981) shows that although the final crop of a thinned stand will be made up of larger trees than an unthinned stand, the total yield of sawlogs say, to $18 \mathrm{~cm}$ top diameter over bark, may not be significantly greater. For normal planting spacings of about $1.7-2.0 \mathrm{~m}$ the production of sawlogs over a normal rotation of between $40-60$ years is not markedly different in a thinned and unthinned crop. Figure 1 shows some of the data for Sitka spruce from published yield models to illustrate this point.

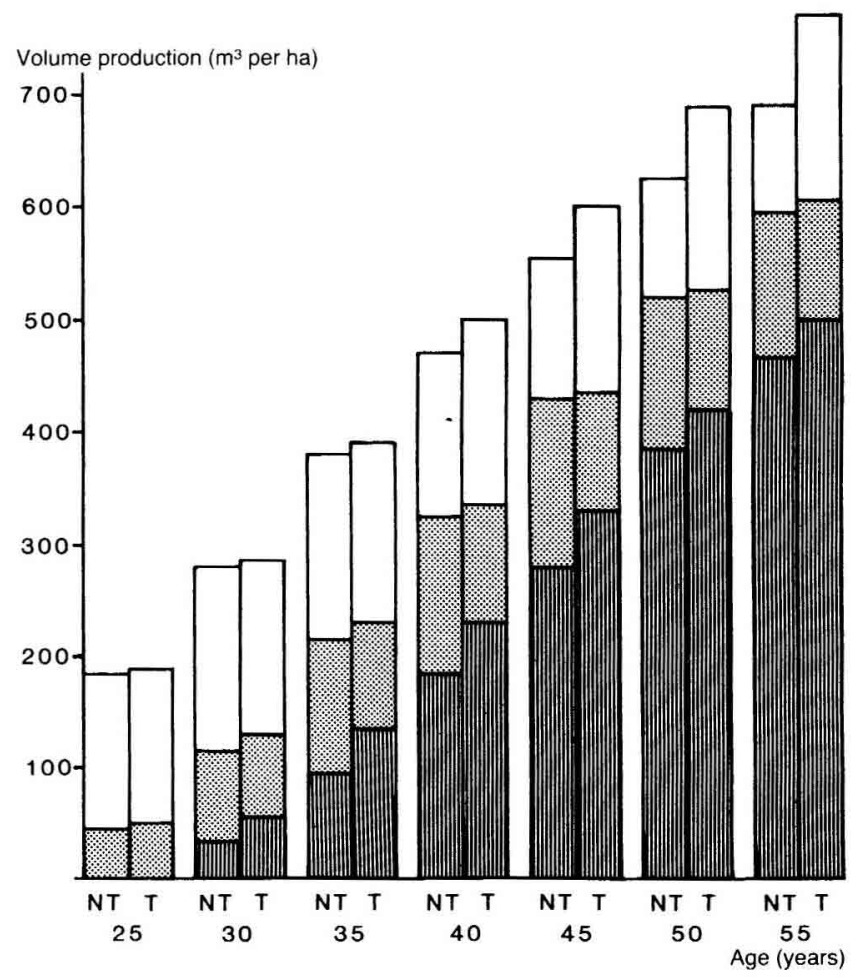

Fig. 1

Total volume production on different rotations for Sitka spruce YC 14 thin $(T)$ and no thin (NT).

Volume total de production pour révolutions différentes pour Picea sitchensis YC 14 éclairci (T) et non éclairci (NT).

Total volume to $7 \mathrm{~cm}$ tdob.

Volume total jusqu'à $7 \mathrm{~cm}$ diamètre sur écorce.

Sawlog volume to $14 \mathrm{~cm}$ tdob.

Volume des billes jusqu'à $14 \mathrm{~cm}$ diamètre sur écorce.

Sawlog volume to $18 \mathrm{~cm}$ tdob.

Volume des billes jusqu'à $18 \mathrm{~cm}$ diamètre sur écorce.

$y$ axis : Volume production $\left(\mathrm{m}^{3}\right.$ per ha.) - Production de volume ( $\mathrm{m}^{3}$ par ha.).

$\mathrm{x}$ axis: Age (years) - Age (années). 
In areas of high windthrow hazard, unthinned crops can as a result of their longer rotation produce substantially higher yields of sawlogs than thinned crops. Table 2 shows sawlog production to $18 \mathrm{~cm}$ top diameter over bark in Sitka spruce for unthinned and thinned crops on sites of high risk of endemic wind damage.

TABI.F. 2

Total volume production of sawlogs $1018 \mathrm{~cm}$ top diameter over bark from unthinned and thinned crops of Sitka spruce to indicated terminal heights (a). Windthrow Hazard Class 5.

Volume total de production des billes jusqu'à $13 \mathrm{~cm}$ de diamètre sur écorce des peuplements de Picea sitchensis - éclaircis et non-éclaircis - jusqu'à des hauteurs terminales spécifiées (a). Classe risque de chablis 5.

\begin{tabular}{|c|c|c|c|c|c|c|}
\hline \multirow[b]{3}{*}{$\begin{array}{l}\text { Expected terminal } \\
\text { height, metres ... }\end{array}$} & \multicolumn{2}{|c|}{ Yield Class 10} & \multicolumn{2}{|c|}{ Yield Class 14} & \multicolumn{2}{|c|}{ Yield Class 18} \\
\hline & Unthinned & Thinned & Unthinned & Thinned & Unthinned & Thinned \\
\hline & 19 & 16 & 19 & 16 & 19 & 15.5 \\
\hline Age, years & 51 & 42 & 39 & 33 & 33 & 27 \\
\hline $\begin{array}{l}\text { Total sawlog } \\
\text { production, } \\
\mathrm{m}^{4} \text { per hectare }\end{array}$ & 200 & 115 & 200 & 100 & 200 & 80 \\
\hline
\end{tabular}

Note (a) : Terminal height is the stand top height when damage is such that the stand would be clear felled. usually when 40 per cent of stems have been blown.

\subsection{Market changes}

The decline in real terms in the price of small roundwood in recent years has brought into question the desirability of starting thinning at traditional ages, or indeed, of thinning at all. Economic appraisals by the Forestry Commission in 1981 indicated that the economic case for thinning largely turned on whether the first thinning did or did not pay (GRAYSON, 1981). Caution about changing from traditional approaches to thinning in order to enhance diameter growth and to select for the best trees as well as concern over the effects on levels of future production programmes led to some reluctance in departing from conventional thinning practice, and as a result, a larger proportion of first thinning has been undertaken at a loss than can be justified on grounds of long-term profitability. Foresters have adopted two main practices to try to make the first thinning profitable. The first is to adopt line thinning or other forms of neutral thinning to raise the mean tree size for a conventional time of first thinning. The second is to delay the time of first thinning usually by five or ten years. This leads to the production of trees which are of a higher value when they are felled and can enhance the discounted revenue despite its delay. Unfortunately both of these actions are likely to increase the risk of wind damage. There is evidence that crops which have been systematically thinned suffer much higher wind damage than selective thinning and delays in the timing of initial thinning operations particularly on exposed sites can lead to very rapid onset of wind damage (Miller, 1983). 


\subsection{Current practice}

Current thinning practice in the Forestry Commission is therefore based to a large extent on assessments of Windthrow Hazard Class and determination of the marginal tree size, that is the size of tree at which revenue just balances harvesting cost. A further analysis of the economics of thinning by the Forestry Commission (Harper, 1984) confirmed earlier ideas and introduced the concept of «threshold surplus ":

(i) Where windthrow hazard is high, no thinning is the preferred option; where hazard is moderate, thinning is likely to be best done at the conventional first thinning age ; on stable sites thinning may best be delayed by five to ten years.

(ii) As a result, 35 per cent of Forestry Commission stands will not be thinned because the potential loss in revenue from premature windblow in thinned stands would render thinning economically unviable.

(iii) In steep terrain, stands are unlikely to be thinned because of high working costs of thinning operations and the high cost of building roads.

(iv) In areas of moderate windthrow risk, faster growing stands reach the height at which they are likely to blow down more rapidly, so thinning is more likely in stands of lower growth rate.

(v) Tables have been produced for forest managers which give the minimum surplus per cubic metre which must be obtained from a first thinning operation to justify starting thinning. The surplus values are termed «threshold surplus " values and they vary with species, growth rate, Wind Hazard Class and road cost. The values may be positive or negative.

In the longer term it is expected that if market conditions improve or harvesting costs fall as a result of increased efficiency, the marginal tree size will fall so that the proportion of crops which can be thinned profitably will increase.

\section{Thinning regimes}

If a crop is to be thinned there are several choices to be made about the age of first thinning, the type of thinning, the intensity of thinning, the thinning cycle, the thinning yield and the age at which thinning should cease. These choices will depend on a number of factors including the objectives of the owner, the markets available at the time and likely to be available in the future, the quality of the stand, its liability to wind damage and the cost of harvesting the timber. The various elements which constitute a thinning regime are discussed below.

\subsection{Thinning type}

Thinnings may be either selective or systematic. The most common type of selective thinning in Great Britain is known as intermediate thinning. It involves removal of most of the suppressed and subdominant trees and also opening up the canopy by breaking up groups of competing dominant and co-dominant trees, so as to 
encourage the development of the better trees and to leave an open and fairly uniform stand. Systematic thinnings are usually one of the varieties of line thinning such as row thinning, strip thinning, chevron thinning, or some combination of these, and are commonly used for the first, and sometimes the second thinning. Systematic thinning is usually cheaper and easier to manage than selective thinning but the operation may leave parts of the crop unthinned and may result in losses of volume production and reduced stand stability. Systematic thinning is usually only considered where the saving in cost in greater than the likely loss of future revenue.

\subsection{Thinning intensity}

The thinning intensity is the rate at which volume is removed, for example $10 \mathrm{~m}^{3} /$ ha/year. In Great Britain, a constant thinning intensity is usually adopted as it is easy to apply, but there is no overriding reason why the rate should not change. Over a wide range of thinning intensities the cumulative volume production is unaffected. At low intensities, stands will be overstocked unless the initial plant spacing is very wide and the cumulative production of usable timber is reduced because some trees die before they are harvested. At high intensities stands do not fully utilise the growing space created by the thinning so that cumulative production of usable timber is reduced. The maximum thinning intensity which can be maintained without causing a loss of cumulative volume production is known as the marginal thinning intensity, and for most species this critical intensity assessed from the time the stand is ready for thinning is about 70 per cent of the maximum mean annual volume increment per year. The marginal thinning intensity is often chosen as it produces the highest possible thinning yields without reducing the total volume production over the rotation, but there are circumstances when it will not be the best choice. If thinnings are difficult to sell, thinning may not be undertaken, or a lower thinning intensity may be adopted. If large sized trees are required as soon as possible, a higher thinning intensity may be adopted. In addition, the greater thinning yields resulting from higher intensities provide greater revenues. Taken together, these features tend to make higher thinning intensities more profitable, although the reduced volume of the final crop has to be taken into account.

\subsection{Thinning cycle}

The thinning cycle is the interval in years between successive thinnings. The cycle has an influence on profitability as the value per $\mathrm{m}^{3}$ of any single thinning depends in part on the scale of the operation. Long cycles involve heavier single thinnings which are usually more profitable, but may increase the risk of windblow owing to the dramatic opening up of the canopy and in extreme cases they may result in some loss of volume production. The choice of thinning cycle will usually depend on local management considerations and on the yield class of the crop. The usual length of thinning cycle is from four to six years in young or fast growing crops, and about ten years for older or slower growing crops.

\subsection{Thinning yield}

The thinning yield is the actual volume removed in any one thinning. If a fully stocked stand is thinned at the marginal thimning intensity, the thinning yield will be 
70 per cent of the maximum mean annual volume increment multiplied by the cycle. This yield can be taken from the time that the stand is ready for first thinning up until the time of maximum mean annual volume increment. In all cases, the thinning yield should not be so heavy that it opens up the stand to the risk of windblow, or to invasion by other woody species, and thinning should not take all the dominant and good quality trees so that none is left to form a reasonable crop after thinning. The yield from understocked stands may be reduced although it will usually be more practicable to leave such stands until they have reached full stocking again. If it is decided to thin an understocked stand, recovery of full stocking would be delayed much less if the thinning yield is reduced by at least one year's cut. For example it may be best to take a three year cut even it if is proposed to thin again in four years' time. Similarly in overstocked stands, the thinning yield may be increased to reduce the stocking level so a six year cut may be taken even if it is proposed to thin again in five years' time. The procedure may be repeated over several thinnings so as to achieve a controlled reduction in stocking. With line thinnings it may not be possible to make precise adjustments to the thinning yield as the harvesting method may reduce the options for varying the yield. For example if row thinning is adopted, the usual options may only be to remove every fourth row ( 25 per cent removal), every third row ( 33 per cent removal) or every second row (50 per cent removal).

\subsection{Timing of thinning}

Stands are not normally thinned unless they are fully stocked. Although this may be judged by visual inspection a more objective method is to measure the basal area of the stand and compare it with a table of threshold basal areas. If the actual basal area is equal to, or greater than, the threshold basal area, the stand is fully stocked and therefore ready for thinning. If the basal area is less than the threshold basal area the stand is not fully stocked and should not be thinned. If however it is intended to thin the stand, then the thinning yield should be reduced to compensate, or the thinning cycle should be extended to allow the stand time to recover.

\subsection{Timing of first thinning}

The decision on time of first thinning varies depending on the species, yield class, initial spacing of the stand, the thinning intensity, and whether thinning will yield a positive net return or not. The normal age of first thinning is later in more widely spaced stands and also for a heavy first thinning as otherwise stocking would be reduced to a level which would cause a loss of cumulative volume production. There are many circumstances where the most profitable treatment will be to begin thinning later than the normal thinning age notably where the standing value of the trees in such a thinning is low. Where the first thinning is delayed, then it will need to be heavier so that the stand returns to the normal stocking level. If the thinning has been considerably delayed it may not be possible to do this in one operation and subsequent thinnings would also need to be heavier than normal to compensate. Thinning normally ceases a few years before the age of maximum mean annual volume increment. 


\section{Control of thinning}

Having determined the thinning regime for stands in a forest which maximises profitability in the long run, it is important to control the volume removed from individual stands when the thinning is marked. Failure to control the volume removed as thinnings can result in over cutting which leads to a loss in volume production or under cutting which depresses profitability. Such failure to control the thinning may also produce an erratic flow of timber to the consumer.

Thinning can be controlled in terms of the number of trees, the basal area, or the volume. Control by the number of trees is not recommended as the result of the thinning is very dependent on the thinning type. If the smallest trees are removed, the stand will be left much denser than if the same number of larger trees are removed. Thinning should therefore be controlled by basal area or volume, and this can either be by the amount removed, or the amount remaining. Control by the amount removed is preferable for four reasons :

(i) It is easier to do.

(ii) It tends to produce a constant and predictable yield of timber which is useful for planning purposes.

(iii) It discourages drastic reduction of the level of the growing stock which can lead to windblow or other damage caused by sudden opening up of the canopy.

(iv) It considerably reduces the effect of inaccurate yield class assessment.

It is essential that the basal area stocking of all stands is checked before thinning to see that it is adequate. Thinning is then usually controlled by the volume removed. This is easier than using basal area as, for a given intensity, the volume removed is constant up to the age of maximum mean annual increment, whereas the basal area removed declines as the stand gets older. The field procedures for assessing basal area stocking and the volume removed are described below.

\subsection{Measuring basal area}

To check whether a stand has reached the threshold basal area it is necessary to take sample measurements of basal area using a relascope or sample plots. If a relascope is used, a number of sample points, usually between 12 to 20 in uniform crops, are chosen systematically or with a point sampling grid on a map throughout the area to be assessed. At each point, all the trees with a $\mathrm{dbh}$ of $7 \mathrm{~cm}$ or more are counted on a $360^{\circ}$ sweep with the relascope. The average count is calculated and multiplied by the relascope factor to give the estimated basal area per hectare of the stand. If sample plots are used a plot size is chosen which includes between 7 to 20 measurable trees ; usually 6 to 10 plots will be laid out in uniform crops. Rectangular plots are used where the planting rows are still clearly visible and circular plots in all other stands. The diameter at breast height $(\mathrm{dbh})$ of all trees of $7 \mathrm{~cm}$ or more are measured and the number of trees in each $\mathrm{dbh}$ class is recorded. The basal area appropriate to each dbh class is multiplied by the number of trees in each class to give the total basal area in each class. The basal areas are added together and divided by the sum of the plot areas to give the estimated basal area per hectare of the stand. 


\subsection{Measuring the volume marked}

Having chosen the thinning yield, the marker proceeds to mark the stand and from time to time checks the yield of thinning marked, modifying the marking as necessary. The check is essentially very simple. To estimate the volume per hectare which is being marked it is necessary to take sample measurements. This is achieved either by using a relascope to estimate basal area which is converted to volume using an estimated form height, or by measuring the basal area of thinnings which fall into sample plots of known area and converting to volume using an estimated tariff number (RoLLINSON, 1985). If the stand is being line thinned, it may be simpler to estimate the volume per hectare of the stand before thinning, and to calculate the volume removed as a percentage of that volume.

In practice the marker starts by marking a representative corner of the stand. The volume marked is estimated as described above and the procedure is repeated several times. If the volume marked is found to be consistently greater or less than the specified thinning yield, the size or number, or both of the trees marked is adjusted accordingly. Marking to this revised standard continues thereafter making only occasional checks. The ultimate objective of thinning control is for the marker to be able to mark the correct thinning yield without needing to use the above procedures except when a new crop type is encountered. Even so it is recommended that occasional checks should be made to confirm the accuracy of marking. If checks show that the thinning yield has not been marked correctly, it is usually simpler to correct the over or under stocking at the next thinning than to mark the stand again. The precision of control will depend upon the expertise and resources available, as well as the nature of the crop being thinned. Normally it should be possible to control yield to within 15 per cent of the target thinning yield, but achieving this degree of control may be unduly expensive in mixtures or in crops that are very variable in other ways.

Reçu le 28 mai 1986.

Accepté le septembre 1986.

Résumé

Contrôle des éclaircies dans les plantations de conifères en Grande-Bretagne

La pratique des éclaircies en Grande-Bretagne a été influencée ces dernières années par la prise de conscience de la menace des chablis dans les plantations, et par la baisse du prix réel des bois de trituration. La Forestry Commission se base, dans sa pratique courante, sur des études de probabilité des chablis, et sur les coûts et revenus des opérations d'éclaircies. Là où les risques de chablis sont grands, on préfère ne pas faire d'éclaircies. Là où les risques sont moyens, l'éclaircie est généralement pratiquée à la date conventionnelle de première coupe d'éclaircie. Là où ces risques sont minimes, la première coupe d'éclaircie peut être repoussée de 5 à 10 ans. Des évaluations économiques sont exécutées pour déterminer si tel ou tel peuplement doit subir une éclaircie, et de quelle manière.

Une description est faite des divers éléments qui composent un système d'éclaircie, à savoir : le type de la coupe d'éclaircie, son intensité, sa périodicité, son rendement et l’âge de la première coupe.

Une description est faite du système de contrôle utilisé lors du martelage de la plantation devant subir l'éclaircie. Ce système repose sur le contrôle du volume enlevé lors de l'éclaircie, et fait appel à des mesures de surface terrière, et du volume marqué pour la coupe. 


\section{References}

Atterson J.A., 1980. Gambling with gales. Paper presented to British Association for Advancement of Science, Salford, UK.

Booth T.C., 1977. Windthrow Hazard Classification. Forestry Commission Research Information Note $22 / 77$.

Edwards P.N., Christie J.M., 1981. Yield Models for Forest Management. Forestry Commission Booklet 48. H.M.S.O., London.

Forestry COMmission, 1984. Great Britain. Census of Woodlands and Trees 1979-1982. Forestry Commission, Edinburgh.

Grayson A.J., 1981. Current Forestry Commission thinking on thinning. Forestry and British Timber, vol. $10, \mathrm{n}^{\circ} 8,46-49$.

HARPER W.H., 1984. Factors affecting the selection of the economically optimum thinning regime. Paper presented to I.U.F.R.O. meeting P4.02.02, Dublin, Ireland, September 1984.

MiLler K.F., 1983. Thinning and damage in conifer forests in the UK. Paper presented to ECE/ UN Seminar Eberswalde, German Democratic Rep., Sept. 1983.

MiLler K.F., 1985. Windthrow Hazard Classification. Forestry Commission Leaflet 85 H.M.S.O., London.

Roluinson T.J.D., 1985. Thinning Control. Forestry Commission Booklet 54 H.M.S.O., London. 